\title{
アークイオンプレーティング法による水素透過性 $\mathrm{Nb}$ 薄膜の作製
}

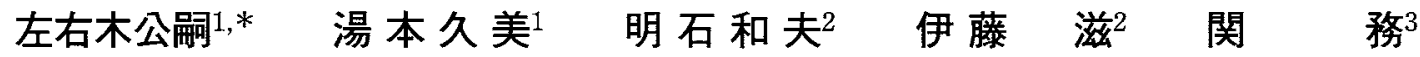 \\ 1東京理科大学基礎工学部材料工学科 \\ 2 東京理科大学理工学部工業化学科 \\ 3東京ガス株式会社基礎技術研究所
}

J. Japan Inst. Metals, Vol. 64, No. 6 (2000), pp. 467-473

(C) 2000 The Japan Institute of Metals

\section{Preparation of Hydrogen Permeable Nb Films by Arc-Ion Plating}

Kimitsugu Soki ${ }^{1, *}$, Hisami Yumoto ${ }^{1}$, Kazuo Akashi², Shigeru Ito ${ }^{2}$ and Tsutomu Seki ${ }^{3}$

${ }^{1}$ Department of Materials Science and Technology, Faculty of Industrial Science and Technology, Science University of Tokyo, Noda $278-8510$

${ }^{2}$ Department of Industrial Engineering Chemistry, Faculty of Science and Technology, Science University of Tokyo, Noda 278-8510 ${ }^{3}$ Fundamental Technology Research Laboratory, Tokyo Gas Co., Ltd., Tokyo 105-0023

In this study, a $\mathrm{Nb}$ film for use as a hydrogen permeable membrane was prepared at $0.4 \sim 5.3 \mathrm{~Pa}$ of $\mathrm{Ar}$, using a PVD method such as arc-ion plating (AIP). Peculiar $\mathrm{Nb}$ droplets $(0.1 \sim 10 \mu \mathrm{m})$ were observed on the membrane. The disconnection of the droplets from the membrane occurred on a flat surface of $\mathrm{Al}_{2} \mathrm{O}_{3}$ substrate, which caused the formation of pinholes. However, a membrane without pinholes was successfully prepared on a rough surface of $\mathrm{Al}_{2} \mathrm{O}_{3}$ by increasing the film thickness to 2 $\mu \mathrm{m}$.

Columnar $\mathrm{Nb}$ crystals grew on the flat substrate and the surface of the film also became flat. Corn-shaped crystals grew on the rough substrate so that the surface of the film was also rough. Since the adhesion of the droplets flying on the rough surface was high, a membrane without pinholes was obtained on the rough substrate.

A geometrical growth model was used to explain the growth of the hemispherical droplets into rugby-ball-shaped crystals by $\mathrm{Nb}$ deposition.

(Received November 4, 1999; Accepted May 8, 2000)

Keywords: hydrogen permeable membrane, arc-ion plating, Niobium film, alumina substrate, physical vapor deposition, morphology

\section{1. 緒言}

都市ガス等の炭化水素を高温 $\left(550^{\circ} \mathrm{C}\right)$ において水蒸気で改 質すると氷素, 一酸化炭素, 二酸化炭素の混合気体となる. これを水蒸気改質反応と呼ぶ1〕。の系から純水素を精製・ 分離する方法としては吸収法, 深冷分離(吸着)法, 膜分離法 などが挙げられる ${ }^{2}$. 特に膜分離法は, 最近の半導体工業に 和计る多量な高純度水素の需要や，次世代主力ェネルギーと しての水素の簡便な供給を満足するるのとして注目されてい $ろ^{2,3)}$. 膜分離法の中では，多孔質基板上にPdを成膜した水 素透過膜が多く研究されている 素透過性，耐酸化性に優れることが要求される．特に高純度 の水素を得るためには，水素以外の気体を透過させないこと が重要である。そのためには透過膜中にピンホールやクラッ ク等がないことが条件となる4,5).

$\mathrm{Pd}$ より10倍以上の水素透過性能を孔つ早金属に Nb， Ta， Vがある6)。乙かし Pdが長年用いら水てきた理由は，水素

\footnotetext{
* 東京理科大学大学院生(Graduate Student, Science University of Tokyo)
}

の透過性を阻害する表面酸化膜をPdは形成しないためであ

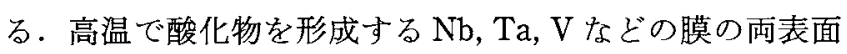
を，Pdで薄くコーティングした多層膜を作製することによ り，これら早金属を水素透過膜として利用寸ることが可能と なる6)．無電解めっき法で作製した透過膜でピンホールをな

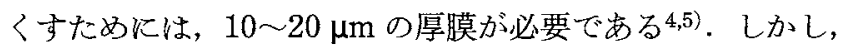
膜厚の増加に伴い水素の透過効率は低下する. そこで本研究 では，プラズマプロセスの一種であるアークイオンプレーテ ィング法 (以下 AIP 法と表記) ${ }^{7,8)}$ という真空蒸着法により, ピンホールのない数 $\mu \mathrm{m}$ の薄い $\mathrm{Nb}$ 膜の作製を行らことを目 的とした：をた水素の透過性を考学ると，基板としては多孔 質体が優れるが，一般に表面の粗いものが多い。しかし，基 板表面の粗さと成膜の関係についてはあまり研究されていな い. そこで本研究では，基板表面の粗さが成膜によ゙のような 影響を扣よぼすかてついても研究した。

\section{2. 実 験 方 法}

Fig. 1 亿本研究で用いた AIP 装置概略図を示す。アーク

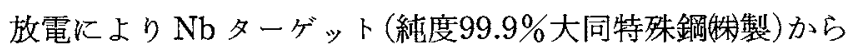




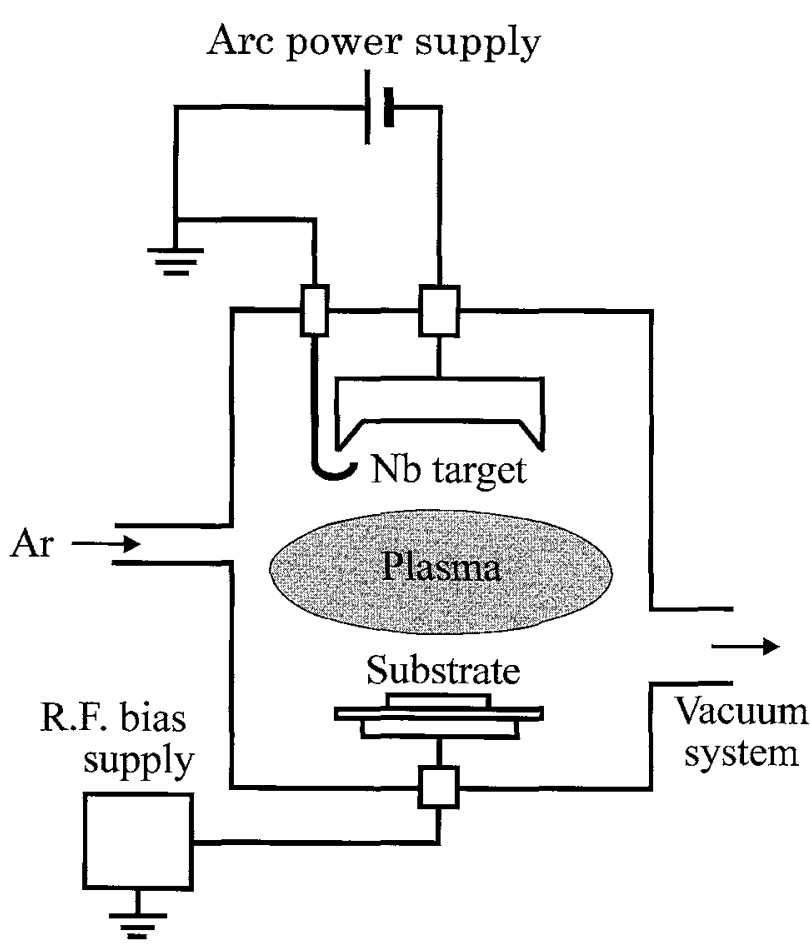

Fig. 1 Schematic drawing of the arc-ion plating (AIP) apparatus.

Table 1 Preparation conditions of $\mathrm{Nb}$ films.

$\begin{array}{ll}\text { Arc current } & 70 \mathrm{~A} \\ \text { Ar gas pressure } & 0.4 \mathrm{~Pa} \\ & 1.3 \mathrm{~Pa} \\ & 5.3 \mathrm{~Pa} \\ \text { RF } & -100 \mathrm{~V} \\ \text { Deposition time } & 20 \mathrm{~min} \\ & 40 \mathrm{~min} \\ \text { Substrate } & \mathrm{Al}_{2} \mathrm{O}_{3}, \mathrm{Si}\end{array}$

蒸発した $\mathrm{Nb}$ が基板上に堆積する.AIP の特徴としては高イ オン化率(約80\%)なため，つき周りの良さが挙げられる。 欠点としては放電によりターゲット表面に微小な溶融物がで き，これが成膜中に液滴(ドロップレット)として取り込まれ る9)。本実験では放電電流值を $70 \mathrm{~A}$ 一定とし，基板には RF バイアス $(-100 \mathrm{~V})$ を印加した。基板には表面の粗れたアル ミナ多孔質体と，比較のためにフラットな $\mathrm{Si}$ ウェを用い た.アルミナ基板は粒径約 $0.5 \mu \mathrm{m} の \mathrm{Al}_{2} \mathrm{O}_{3}$ 粒子を焼結した もので, 平均細孔径は約 $1 \mu \mathrm{m}$, 空孔率は約34\%であった。

Table 1 に本実験に打忷る成膜条件を示す。背圧は $1.3 \times$ $10^{-3} \mathrm{~Pa}$ で，導入する $\mathrm{Ar}$ ガス圧は 0.4 $\mathrm{Pa}, 1.3 \mathrm{~Pa}, 5.3 \mathrm{~Pa}$ の 3 種類で行った. Arの流量はマスフローで制御し, 流量は 30.0 SCCM で一定とした.

アルミナ基板上へ成膜した Nb膜中のピンホールの有無を 調ベるために，メタノール滴下試験を行った。予めオキシド ールで黄色 $(\mathrm{pH}$ 值 4$)$ に変色させた $\mathrm{pH}$ 試験紙上に試料を置 き, 膜表面にメタノール $(\mathrm{pH}$ 值 6〜7, 試験紙の呈色; 黄緑 色）を滴下した。アルミナ基板は多孔体でするから，も乙膜 にピンホールが存在すれば， $\mathrm{pH}$ 試験紙までメタノールが透 過するため, $\mathrm{pH}$ 試験紙に黄緑色の斑点が生じるはずでめ る.これによりピンホールの有無を調べた。
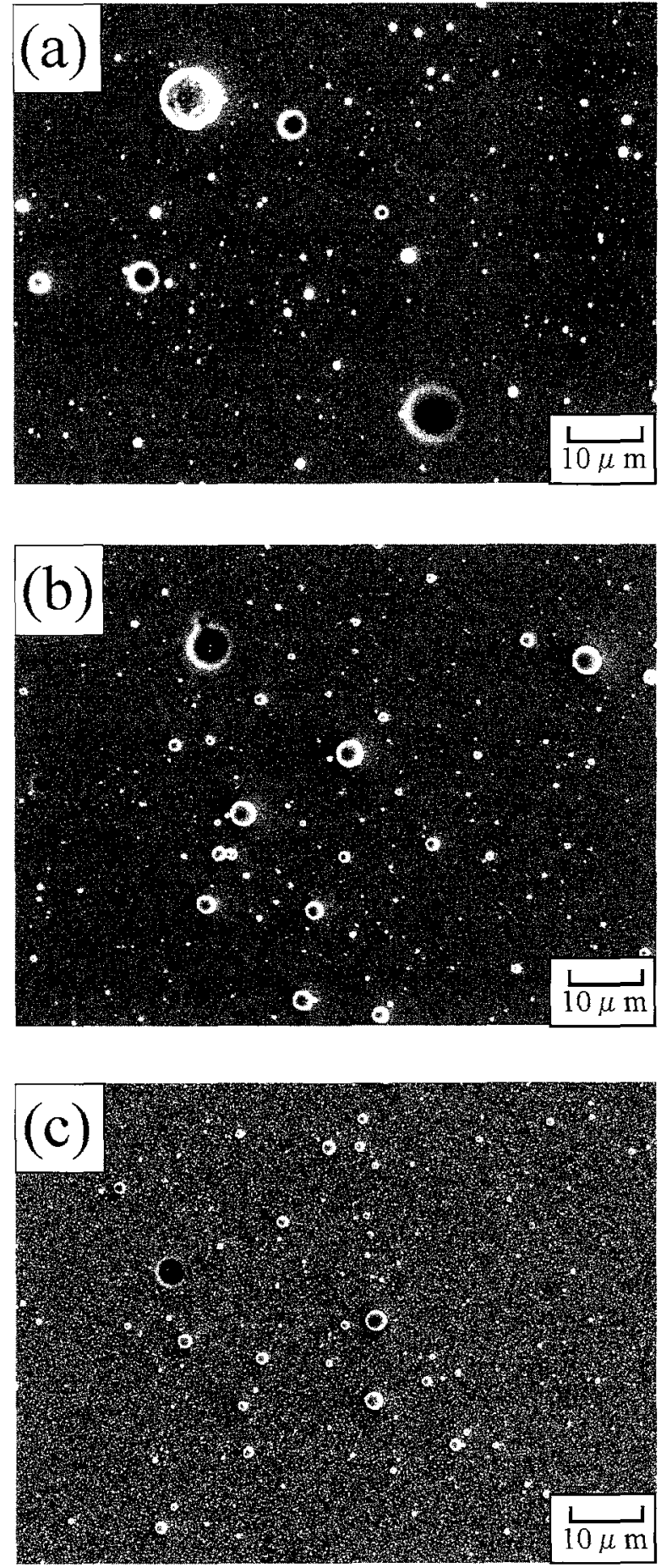

Fig. 2 SEM image of $\mathrm{Nb}$ films prepared on $\mathrm{Si}$ wafer for 20 min: (a) 0.4 Pa, (b) $1.3 \mathrm{~Pa}$, and (c) $5.3 \mathrm{~Pa}$ of Ar gas pressure.

\section{3. 結果および考察}

\section{$3.1 \mathrm{Ar}$ ガス圧の影響}

Fig. 2 飞 $\mathrm{Si}$ 基板上の $\mathrm{Nb}$ 膜表面 SEM 写真を示す．白い 球状の粒子がターゲットから飛来した Nbのドロップレット (液滴)で，よく $\mathrm{AIP}$ 法烧いて観察さ机る。ドロップレッ トの粒径分布は幅広く，0.1〜10 $\mu \mathrm{m}$ であった。最大ドロッ プレットのサイズは，ガス圧が $0.4 \mathrm{~Pa}$ に和いて約 $10 \mu \mathrm{m}$, $1.3 \mathrm{~Pa}$ で約 $5 \mu \mathrm{m}, 5.3 \mathrm{~Pa}$ で約 $3 \mu \mathrm{m}$ と, ガス圧の増加とと 


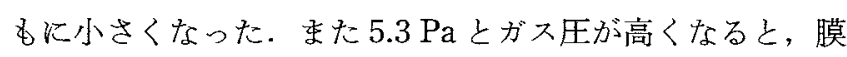
一面を覆ら径 $0.1 \sim 0.3 \mu \mathrm{m}$ 程度の微細なドロップレットの 数が顕著になった.

成膜速度を $\mathrm{Si}$ 基板上の膜の断面 SEM 像から算出した。 その結果, $0.4 \mathrm{~Pa}$ と $1.3 \mathrm{~Pa}$ では約 $46 \mathrm{~nm} / \mathrm{min}$ であった。し かし $5.3 \mathrm{~Pa}$ では約 $33 \mathrm{~nm} / \mathrm{min}$ になり，成膜速度は約 $30 \%$ 低

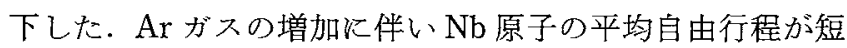
くなりターゲット近傍のテャンバ壁への蒸着量が多くなっ た. そのため基板に到達する $\mathrm{Nb}$ 原子の数が減少したと考光 られる。

Fig. 3 亿結晶粒サイズのガス圧括よび成膜温度依存性を示 す. AFM 像で求めた結晶粒は, $0.4 \mathrm{~Pa} て ゙$ 約 $32 \mathrm{~nm}, 1.3 \mathrm{~Pa}$

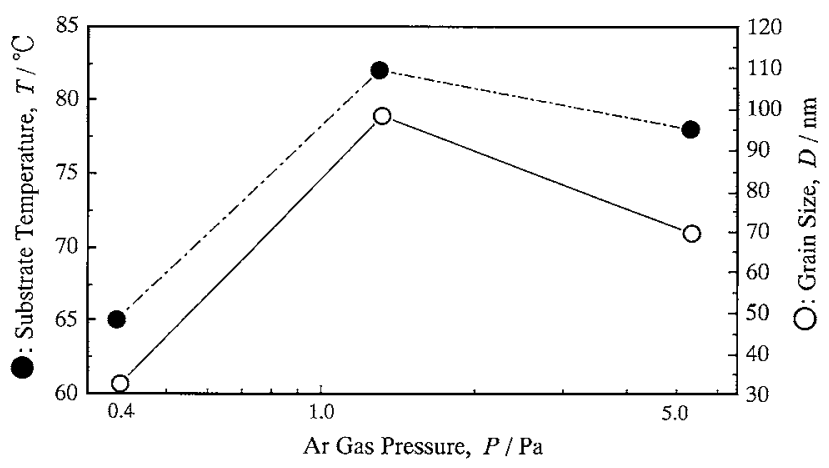

Fig. 3 Dependence of $\mathrm{Nb}$ grain size on Ar gas pressure and temperature of substrate (deposition time: $20 \mathrm{~min}$ ).
で約 $98 \mathrm{~nm}, 5.3 \mathrm{~Pa}$ のとき約 $69 \mathrm{~nm}$ であった。成膜温度はガ

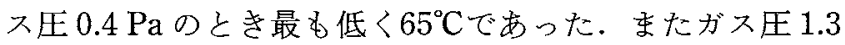
$\mathrm{Pa}$ のとき $82^{\circ} \mathrm{C}$ と最も高温になり， $5.3 \mathrm{~Pa}$ になると $78^{\circ} \mathrm{C}$ に下 がった。 ガス圧に対して成膜温度と結晶粒の大きさは同じよ らな傾向を示した。一般に成膜温度が高い注ど，膜の結晶粒 は大きく成長する(10)ため，結晶粒の変化は成膜温度で説明 できた。

\section{2 基板表面形状と成膜形態}

Fig. 4 に Si 基板抏よびアルミナ基板上に成膜した $\mathrm{Nb}$ 膜 の表面特よび断面 SEM 写真を示す. $\mathrm{Si}$ 基板の場合 (a) と Fig. 2 から，ドロップレットKよる表面粗れを無視すれば， $\mathrm{Si}$ 基板上の $\mathrm{Nb}$ 膜表面はなめらかであった。（c）アルミナ基 板上の $\mathrm{Nb}$ 膜の場合, 表面は著しく粗れ，大きさ約 $0.5 \sim 1$ $\mu \mathrm{m} の$ 粒Kなった。（b) Si 基板上の $\mathrm{Nb}$ 膜断面は，幅約 0.1 $\mu \mathrm{m}$ の柱状晶で構成されていた。（d）アルミナ基板上の $\mathrm{Nb}$ 膜断面は， $\mathrm{Si}$ 基板の場合と異なりコーン型 $\mathrm{Nb}$ 結晶が形成 された．基板に垂直に成長するコーン型 $\mathrm{Nb}$ 結晶は大きく成 長できるが，斜めに成長した結晶は隣の結晶に当たると成長 は阻害された.コーン型結晶が成長した要因としては，基板 の表面形状の違いが考光られるため，アルミナ基板の研磨を 行った。

Fig. 5 にアルミナ基板のSEM 写真を示す.（a）研磨しな い場合, 基板表面以は $0.5 \mu \mathrm{m}$ 弱の $\mathrm{Al}_{2} \mathrm{O}_{3}$ 粒子がみられ，凹 凸の激しい形状をしている。（b)表面をバフ研磨すると，泀
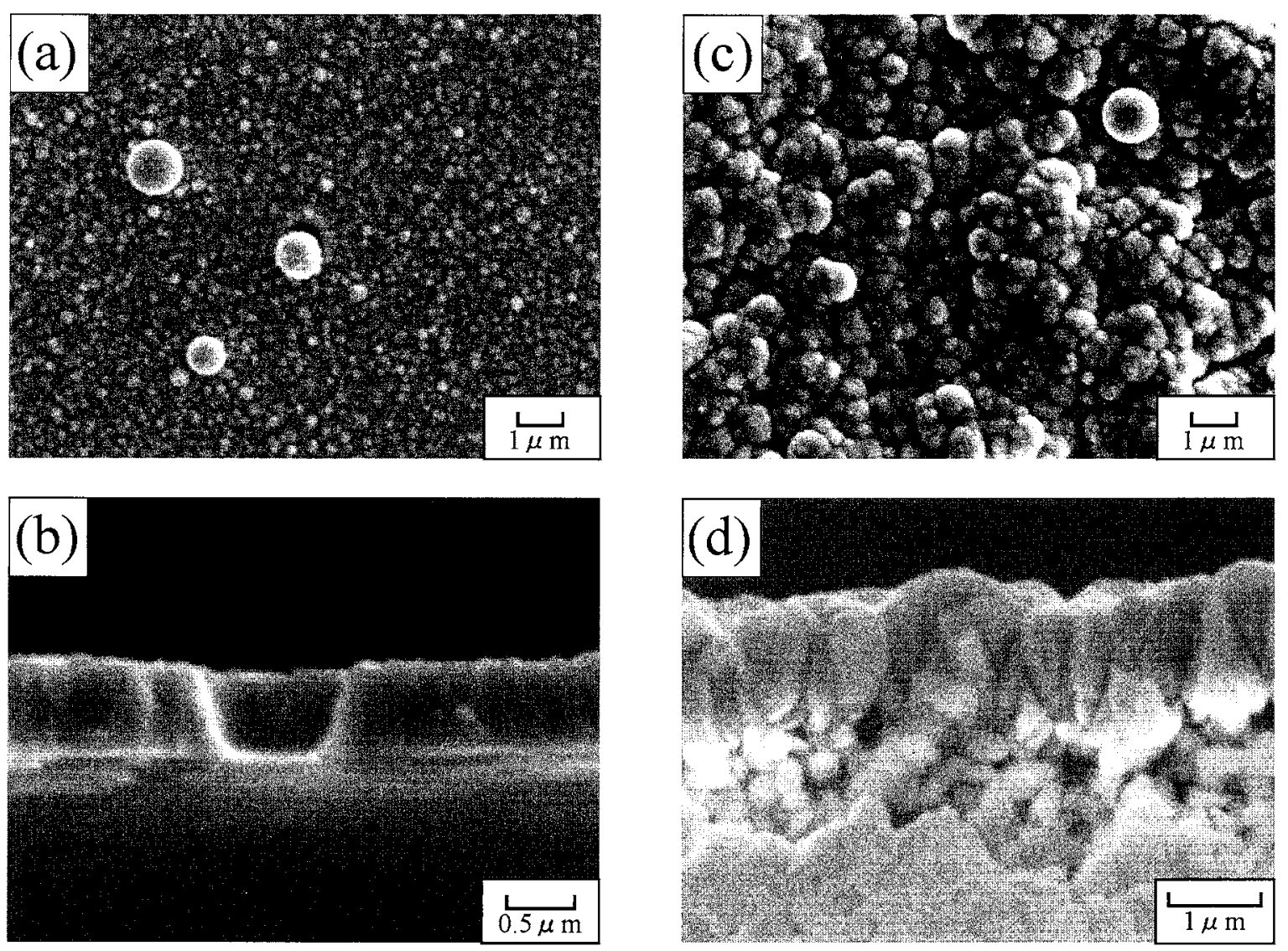

Fig. 4 SEM image of $\mathrm{Nb}$ films prepared at $5.3 \mathrm{~Pa}$ of Ar gas pressure for $20 \mathrm{~min}$ : (a) (b) Si wafer and (c) (d) $\mathrm{Al}_{2} \mathrm{O}_{3}$ substrate. (a) and (c) are surface images, (b) and (d) are cross-sectional images. 

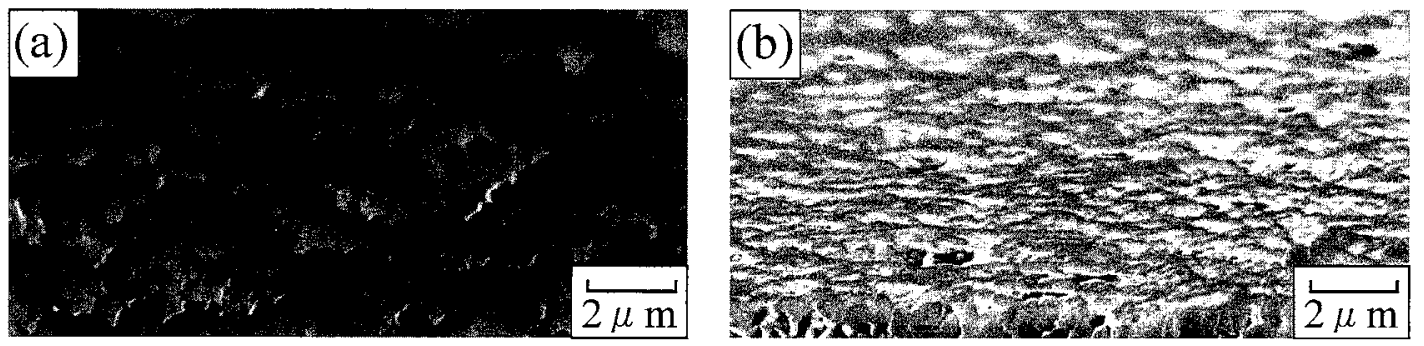

Fig. 5 SEM image of $\mathrm{Al}_{2} \mathrm{O}_{3}$ substrates: (a) nonpolished and (b) polished surfaces.
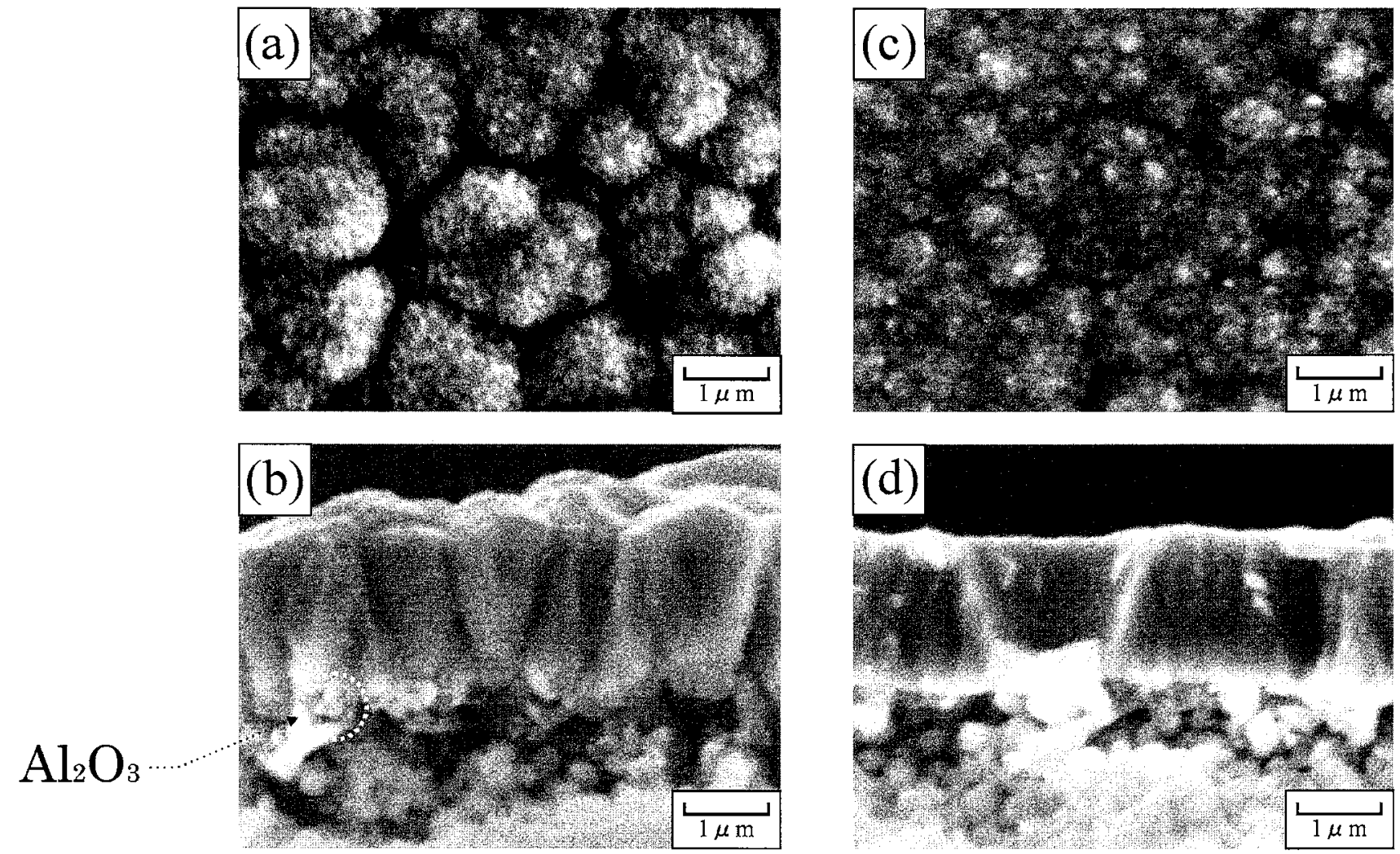

Fig. 6 SEM image of $\mathrm{Nb}$ films prepared on $\mathrm{Al}_{2} \mathrm{O}_{3}$ substrates at $5.3 \mathrm{~Pa}$ of Ar gas pressure for 40 min: (a) (b) nonpolished, (c) (d) polished. (a) and (c) are surface images, (b) and (d) are cross-sectional images.

ぼ平滑なアルミナ表面が得られた。

Fig. 6 亿研磨岁りとなしのアルミナ基板上飞作製した Nb 膜の表面掠よび断面 SEM 像を示す(成膜時間40分)。(a) 研 磨なしのアルミナ基板上の $\mathrm{Nb}$ 膜は約 $0.8 \sim 2 \mu \mathrm{m}$ の粗い粒 であるが，(c) 研磨した基板上の膜は径約 $0.3 \mu \mathrm{m}$ の微細な 粒になった。（b)研磨していない基板上の膜の断面は，幅 1 $\mu \mathrm{m}$ 前後のコーン型結晶であった（d)研磨した基板上には 幅の狭い(約 $0.3 \mu \mathrm{m}$ ) 柱状晶が形成されていた。これは Fig. 4 (b) 亿示した $\mathrm{Si}$ 基板上の $\mathrm{Nb}$ 膜断面に酷似している. 以上 の結果より，アルミナ基板上の $\mathrm{Nb}$ 膜に観察されたニーン型 結晶は，基板の種類ではなく基板表面の粗さとより与えられ たことが分かった。

\section{3 ピンホール形成要因}

Fig. 2 の $\mathrm{Si}$ 基板上の $\mathrm{Nb}$ 膜表面に招いて，各々のガス下 で顕著なサイズのドロップレットと，それに似た大きさのピ ンホールがとも隹察された，Fig. 4(a)では剥離途中のド ロップレットが観察され，(b)の断面写真においてはドロッ プレットが剥離した結果形成されたと思われる“すり錰”状 のくぼみが観察された。 以上の結果上り， $\mathrm{Si}$ 基板上の $\mathrm{Nb}$ 膜に観察されたピンホールは, 成膜初期に膜へ付着したド口 ップレットが剥離したものと考克られる。また，研磨ありの アルミナ基板上の $\mathrm{Nb}$ 膜炕もドップレット剥離痕が観察さ れた(Fig. 6(d)). SEM 観察に括いて,ドロップレットの剥 離痕はフラットな基板上の膜で顕著であり, 研磨なしのラフ な基板上の膜では観察されなかった。

Table 2 そヌノール滴下によるピンホール確認試験結果 とドロップレットのサイズ分布, 成膜時間の関係を示す．表 面研磨したアルミナ基板上の $\mathrm{Nb}$ 膜に䏡いては，全ての試料 で黄緑色の斑点が確認された. 表面研磨なしのアルミナ基板 上の $\mathrm{Nb}$ 膜の場合, ガス圧 $0.4 \mathrm{~Pa}$ で, 成膜時間20分 (膜厚約 $0.9 \mu \mathrm{m})$ の試料棌いて若干の黄緑色斑点が確認されたが, 他の試料では確認されなかった。.以上の結果より, 研磨なし のラフなアルミナ基板上に成膜したドロップレットは剥離し 
Table 2 Existence of pinholes in Nb films.

\begin{tabular}{|c|c|c|c|c|c|c|c|}
\hline \multirow{2}{*}{\multicolumn{2}{|c|}{$\frac{\mathrm{Al}_{2} \mathrm{O}_{3} \text { substrate }}{\text { Ar gas pressure }(\mathrm{Pa})}$}} & \multicolumn{3}{|c|}{ Nonpolished } & \multicolumn{3}{|c|}{ Polished } \\
\hline & & 0.4 & 1.3 & 5.3 & 0.4 & 1.3 & 5.3 \\
\hline \multicolumn{2}{|c|}{ Droplet size $(\mu \mathrm{m})$} & $0.1-10$ & $0.1-5$ & $0.1-3$ & $0.1-10$ & $0.1-5$ & $0.1-3$ \\
\hline \multirow[t]{2}{*}{ Deposition time } & $20 \mathrm{~min}$ & $x$ & 0 & 0 & $x$ & $x$ & $x$ \\
\hline & $40 \mathrm{~min}$ & 0 & 0 & 0 & $x$ & $x$ & $\times$ \\
\hline
\end{tabular}

にくいことが分かった。これはコーン型 $\mathrm{Nb}$ 結晶からなる膜 表面は粗れが著しく，飛来したドロップレットに対しアンカ 一効果が働き，付着力が增したためと考兄られる。また，サ イズの大きいドロップレット汪ど剥離しやすく，大きさが 5 $\mu \mathrm{m}$ を越えるドロップレット関してはアンカー効果が十分

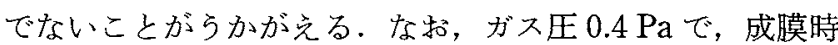
間が 40 分 (膜厚約 $1.8 \mu \mathrm{m}$ ) の試料ではピンホールが確認され なくなったが，これは膜厚の増加によりドロップレットが埋 め込李れ，からアンカー効果を与兄るコーン型 Nb 結晶も大 きく成長したため剥離が抑制されたるのと考兄られる.

\section{4 コーン型結晶の成長機構}

ラフなアルミナ基板上の $\mathrm{Nb}$ 膜に扎いてドロップレットの 剥離が抑制された理由は，コーン型 $\mathrm{Nb}$ 結晶の成長により膜 表面が著しく粗れたためである.よってコーン型結晶の成長 機構と基板表面形状の関係汇ついて考察する.

Fig. 7 にアルミナ基板表面の凹凸と膜形熊の関係を表した モデル図を示寸．実線で描かれた円が基板の $\mathrm{Al}_{2} \mathrm{O}_{3}$ 粒子で 峁る。今，凹入角效果 ${ }^{11}$ 拉上び成膜途中での新たな核形成 等は考克ない，膜はこの粒表面に対し均一な速度で成長して いくと仮定すると，专る $\mathrm{Al}_{2} \mathrm{O}_{3}$ 粒子上に成長した $\mathrm{Nb}$ 結晶 と, 隣接する $\mathrm{Al}_{2} \mathrm{O}_{3}$ 粒子上飞成長した $\mathrm{Nb}$ 結晶の粒界面は, 互いの粒の中心加ら等しい距離に来る。つまり二等辺三庙形 となるため，(a) $\mathrm{Al}_{2} \mathrm{O}_{3}$ 粒子が表面に一様に並んでいる場合， その界面は基板に対して垂直になる。乙かし(b) $\mathrm{Al}_{2} \mathrm{O}_{3}$ 粒子 の重心の位置に高低差がある場合，その界面は垂直な方向よ り低い粒の方へ傾く。このような成長をした結果，低位置の $\mathrm{Al}_{2} \mathrm{O}_{3}$ から成長した $\mathrm{Nb}$ 結晶粒の成長は阻害される，高位置 の粒上に成長した Nb 結晶は逆にコーン状に大きく成長す る、そのため結晶粒の大きさが不均一になり，粗れの著しい 表面になったと考光られる。

\section{$3.5 \mathrm{Nb}$ 膜中のドロップレットの形態}

Fig. 8 とドロップレットを舍を $\mathrm{Nb}$ 膜の断面 SEM 写真を 示す．（a）フラットな $\mathrm{Si}$ 基板上飞成長すると， $\mathrm{Nb}$ 膜は柱状 構造をとり，表面はフラットになる。この写真の場合，大き さ約 $1 \mu \mathrm{m}$ の半球状ドロップレットである.ドロップレット 上の $\mathrm{Nb}$ の堆積量がドロップレットの大きさに比べ不十分な ため，剥離しかかっている。

(b)同じ基板でる，ドロップレットの形は異なる。この場 合ドロップレットは一見，楕円状にみ光るが，これは大きさ 約 $0.5 \mu \mathrm{m}$ の半球状のドロップレットを核とし，この上に約 3 倍の厚さの Nb が棈円状に成長したものである。ドロップ レット上に $\mathrm{Nb}$ が厚く堆積しているため，このようなドロッ

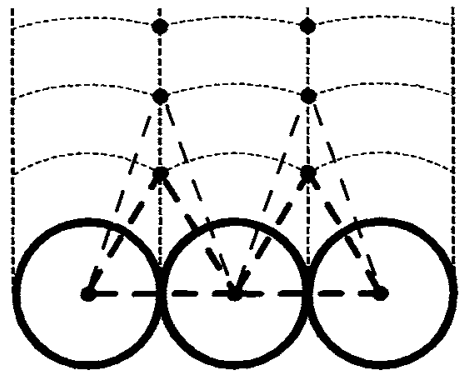

(a)

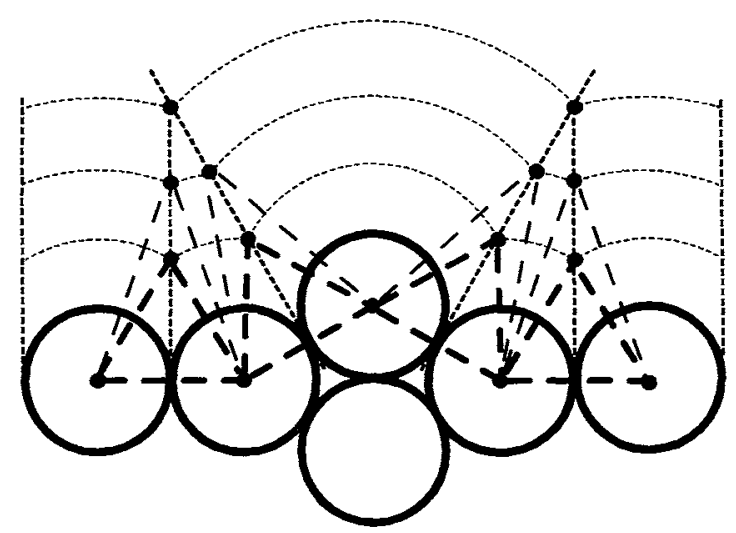

(b)

Fig. 7 Growth model of $\mathrm{Nb}$ films on granular substrates: (a) grains were uniformly in line and (b) not uniformly in line.

プレットは剥離し難いと思われる。つまり，フラットな膜へ 飛来したドロップレットでる，ドロップレット上に十分な量 の $\mathrm{Nb}$ が堆積すれば剥離しないと考完られる。

(c)ラフなアルミナ基板上《成長すると, $\mathrm{Nb}$ 膜自身はコ ーン型結晶で構成され，表面はラフになる．写真は(b)と同 程度の大ささのドロップレットが飛来してきたものである。 フラットな膜へ飛来したドロップレットは柱状に成長した が，ラフな膜へ飛来したドロップレットはコーン状に成長し た。柱状火成長したドロップレットは，核となるドロップレ ットと同程度の幅をもつ。これに対しコーン状に成長したド ロップレットは，核となるドロップレットの倍以上の幅をる っている。つまりラフな膜上のドロップレットの方がより大 きく成長する。

従来，成膜中のドロップレットの形態についてはあまり研 究されていない，そこでラフ执よびフラットな膜上の半球状 ドロップレットの形態変化について以下のように考察した.

Fig. 9 亿半球状ドロップレットの成長モデルを示す. 成膜 が進屯につれ，ドロップレット上にも Nbが堆積していく が， その堆積速度㤃方位によらず一定であると仮定する。

(a)フラットな膜へ飛来したドロップレットの半径をてと する．図のようにドロップレットの中心 0 を通る断面に特 いて，単位時間当たりの膜の婎積量(成膜速度)を $v$ とする。 時間 $t$ に持けるドロップレットの軌跡 $Q(x(t), y(t))$ は，O とのなす角を $\theta$ として以下の式で表される。

$$
x(t)=(v t+r) \cos \theta
$$



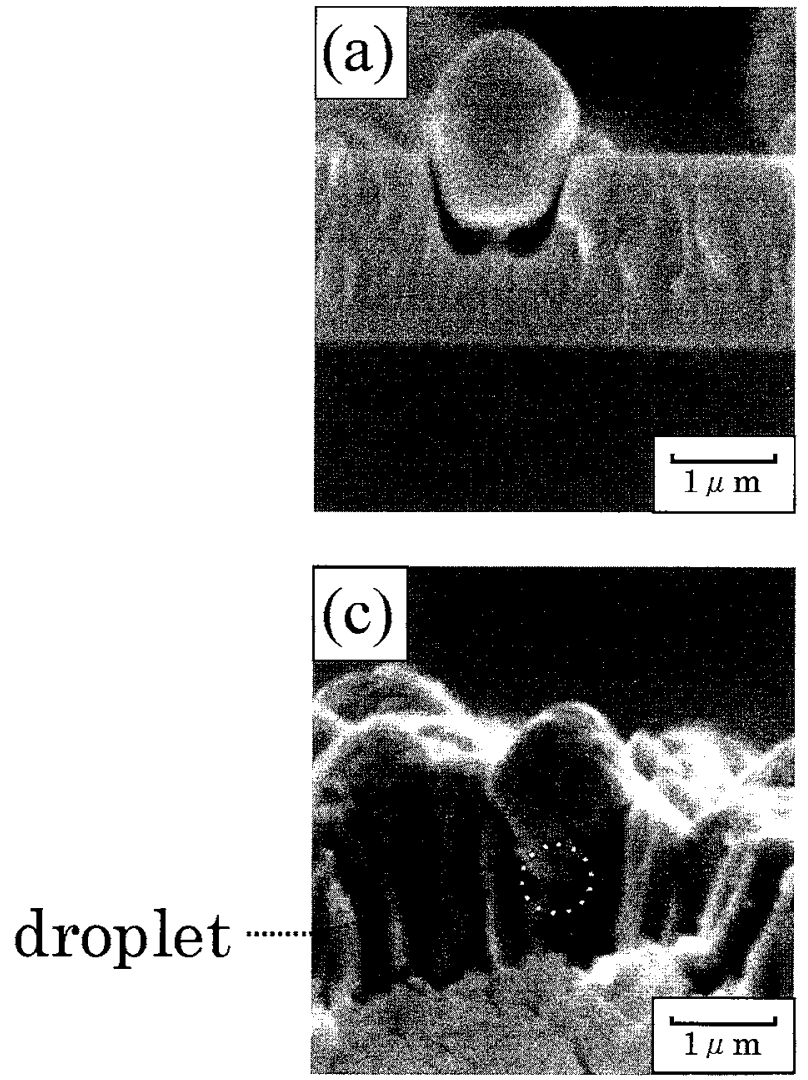

Fig. 8 Typical cross-sectional SEM image of $\mathrm{Nb}$ films including droplet, prepared at 1.3 $\mathrm{Pa}$ of $\mathrm{Ar}$ gas pressure for 40 min: (a) (b) Si wafer, (c) nonpolished $\mathrm{Al}_{2} \mathrm{O}_{3}$ substrate.

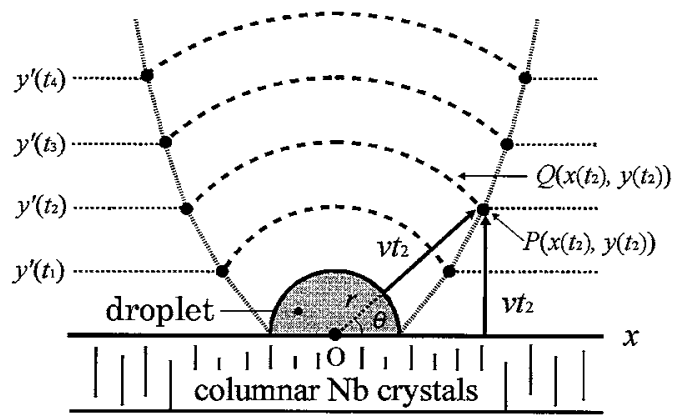

Si wafer

(a)

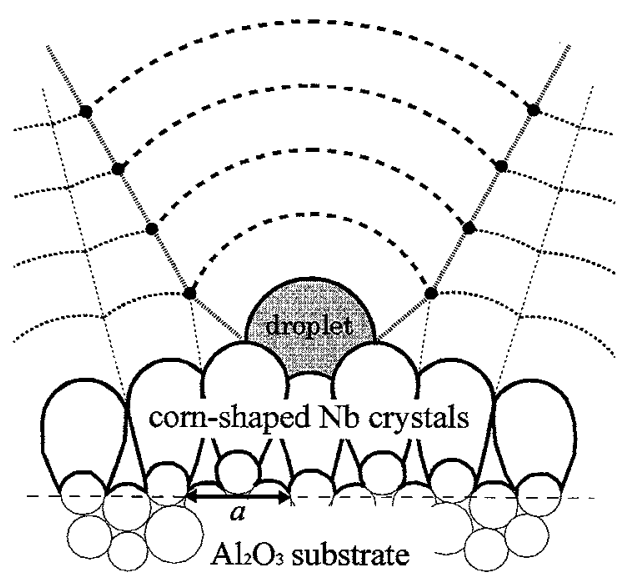

$a$ : roughness

(b)

Fig. 9 Growth model of Nb droplet: (a) on flat surface and (b) on rough surface.

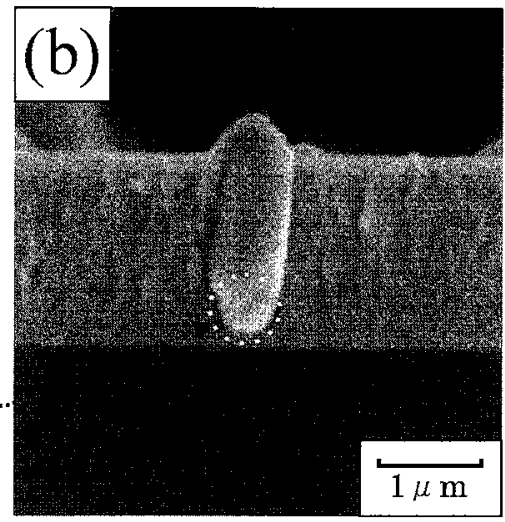

$$
\begin{gathered}
y(t)=(v t+r) \sin \theta \\
(0 \leqq \theta \leqq \pi)
\end{gathered}
$$

式(1)，(2)上り

$$
x^{2}+y^{2}=(v t+r)^{2}
$$

となり, 軌跡 $Q(x(t), y(t))$ 性半球状になる。そのときド口 ップレットを除くフラット部に堆積する $\mathrm{Nb}$ 膜の厚さ $y^{\prime}(t)$ は

$$
y^{\prime}(t)=v t
$$

となる。この堆積膜とドロップレットの界面 $P(x(t), y(t))$ の $y$ 座標は等しくなければいけない。つまり，

$$
(v t+r) \sin \theta=v t
$$

となる.膜の唯積量 $y^{\prime}(t)$ が

$$
y^{\prime}(t)=v t_{n}=n r(n=1,2,3 \cdots)
$$

になるときの界面 $P\left(x\left(t_{n}\right), y\left(t_{n}\right)\right)$ を Fig. 9(a)飞示す. 同時 にドロップレット表面の軌跡 $Q\left(x\left(t_{n}\right), y\left(t_{n}\right)\right)$ 女示す.

堆積量が少ない $\left(y_{1}^{\prime}, y_{2}^{\prime}\right)$ 場合, 横方向八の成長がみられ， ドロップレットは括わん型に成長する。実験結果より，ドロ ップレットの剥離痕には，すり鉢状のものが多い，従ってこ の形態のドロップレットが剥離しやすいと考えられる。堆積

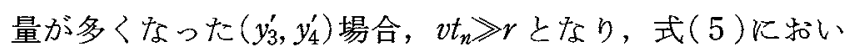
$\tau$

$$
\sin \theta \fallingdotseq 1
$$

が成り立つ.つ委り， $\theta$ は限りなく $\pi / 2$ に近づき，ドロップ レットは図のような柱状に近い形になる。

ドロップレットが括わん型から柱状に形態が変わるための 条件は $x<y$ である。つり横方向の成長より繸方向の成長 が優る。従って式(1)と（2）より

$$
\left(v t_{n}+r\right) \cos \theta<\left(v t_{n}+r\right) \sin \theta
$$

となる。式( 8 )を満たす $\theta$ の範囲は

$$
\frac{\pi}{4}<\theta<\frac{3}{4} \pi
$$

であるから，式(9)と（5)から式（８）は

$$
\frac{r}{\sqrt{2}-1}\left(v t_{n}+r\right)<v t_{n}
$$

となる。ドロップレットが柱状成長に移行するための堆積量 $y^{\prime}(t)=v t_{(x<y)}$ は

$$
v t_{(x<y)}>\frac{r}{\sqrt{2}-1} \fallingdotseq 2.5 r
$$

となる.Fig. 8(b)K拈いても，核となるドロップレットの 半径の 3 倍以上 $\mathrm{Nb}$ が堆積したため, 柱状になっており，こ 
の理論と一致する.

(b)ラフな膜へ飛来したドロップレットの成長はFig. 7 に 示した理論で説明できる.ドロップレットの凸部から成長す る場合は大きくューン状になる。矢の結果(a)のドロップレ ットと比較して横方向に大きく成長し，ドロップレットはく さびのように膜へくいこむ形になる，ラフな底面に飛来する ためのアンカー効果に加党，このドロップレットの形状も剥 離抑制要因になると考光られる。

またこのモデルから，ドロップレットの大きさは基板表面 の粗さ $a$ と同程度であることが分かる。つまり，基板の粗 れがドロップレットやコーン型結晶の大きさと同程度になる と，ドロップレットは剥離しなくなる．Fig. 6(a)の場合， $\mathrm{Nb}$ 膜表面が $0.8 \sim 2 \mu \mathrm{m}$ と，ドロップレットの大きさと同程 度の粒になったとき，ドロップレットは剥離しなかった。

Fig. 5(a)より，このときの基板の粗れはドロップレットの 大きさと同程度であった。つ方我々のモデルと笑験結果は よく一致した.

\section{4. よ め}

（1）表面の粗い $\mathrm{Al}_{2} \mathrm{O}_{3}$ 基板を用いると，膜厚が約 $2 \mu \mathrm{m}$ 以 上でと゚ンホールのない水素透過性 $\mathrm{Nb}$ 薄膜を AIP 法で作製
できた。

(2) ドロップレットの剥離がピソホール形成要因で，ドロ ップレットの剥離はフラットな基板上の膜で顕著に観察され た。

（3）凹凸の激しいアルミナ基板の場合，コーン型 $\mathrm{Nb}$ 結晶 膜が得られ，平滑な基板の場合，柱状晶が得られた。

\section{文献}

1) K. Onishi: The Latest Technologies of Hydrogen-Absorbing Alloys., CMC Co., Ltd., Tokyo, (1994), pp. 176-183.

2) Y. Osumi: Suiso-chozou goukin., Yonosyobo Ltd., Tokyo, (1985), pp. 157-172.

3) Y. Osumi: Suiso-kyuzo goukin no hanashi., Agne Co., Ltd., Tokyo, (1990), pp. 145-153.

4) N. Itoh: Sekiyu Gakkaishi., Vol. 33(1990), 136-146.

5) E. Kikuchi: Sekiyu Gakkaishi., Vol. 39(1996), 301-303.

6) Robert E. Buxbaum, Andrew B. Kinney: Ind. Eng. Chem. Res., 35(1996), 530-537.

7) T. Takeda: Hyomen Gijutsu., Vol. 48(1997), 31-35.

8) K. Yamamoto: Hyomen Gijutsu., Vol. 48 (1997), 446-453.

9) Nissin Electric: Multi-arc houshiki PVD hou no genri to tokucho., Nissin Electric Co., Ltd., Kyoto, (1989), pp. 1-19.

10) Rigaku Corporation: $X$-sen kaisetu no tebiki., Rigaku Co., Ltd., Tokyo, (1989), pp. 75-79.

11) Japanese Association for Crystal Growth: Kettsho seicho hand book., Kyoritsu Shuppan Co., Ltd., Tokyo, (1995), pp. 169-177. 